Проценко О. А., кандидат філологічних наук, доцент кафедри української літератури Запорізького національного університету

\title{
СПЕЦИФІКА ТВОРЧОГО СПІВВІДНОШЕННЯ ІСТОРИЧНОЇ ПРАВДИ І ХУДОЖНЬОГО ДОМИСЛУ В РОМАНІ 3. ЛЕГКОГО «ТАРАСОВІ СТРАСТІ»
}

У статті з'ясовано естетичне, композииійне навантаження документів (відгуків, виписок, листів, безпосередніх фрагментів творів Т. Шевченка) та розкрито роль творчого домислу в художньому відтворенні подій, постатей, явищ у романі 3. Легкого «Тарасові cmpacmi».

Ключові слова: документ, достовірність, домисел, історична та художня правда, факт, художня біографія.

B cтатье рассматриваются эстетические, композиционные особенности документов (отзывов, выписок, писем, непосредственных фрагментов произведений T. Шевченко) и раскрыта роль творческого домысла в художественном воспроизведении событий, фигур, явленийв романе 3. Легкого «Тарасовы страсти».

Ключевые слова: документ, достоверность, домысел, историческая и художественная правда, факт, художественная биография.

In the article aesthetic, composite peculiarities of documents (references, extractions, letters, direct fragments from literary works by T. Shevchenko) are considered and the role of creative fantasy in reproduction of events, personalities, phenomena in the novel by Z. Legkii «Tarasovi strasti» are disclosed.

Key words: document, authenticity, fantasy, historical and fiction truth, fact, fiction biography.

У сучасному літературному процесі жанр художньої біографії набуває все більшої популярності. За останні роки лише українським письменникам присвячено твори Р. Горака «Кров на чорній ріллі: есе-біографія про Василя Стефаника» (2010), В. Сшкілєва «Усі кути трикутника. Апокриф мандрів Григорія Сковороди» (2012), трилогія С. Процюка «Троянда ритуального болю. Роман про Василя Стефаника» (2010), «Маски опадають повільно. Роман про Володимира Винниченка» (2011), «Чорне яблуко. Роман про Архипа Тесленка» (2013) та інші. Головне завдання авторів художніх біографій - відтворити складну долю відомої постаті, ознайомитись із соціальною, психологічною, духовною атмосферою, у якій вона жила і під впливом якої формувалася лінія їі 
поведінки. Серед тих, хто досліджував особливості розвитку, специфіку творення та жанрову своєрідність таких творів, - Є. Баран, І. Братусь, О. Галич, Г. Грегуль, І. Данильченко, О. Дацюк, А. Меншій, Л. Мороз, М. Сиротюк, I. Ходорківський та інші.

Серед нинішніх, найбільш знаних майстрів слова, варто згадати прозаїка Зіновія Легкого - автора багатьох поважних книг, зокрема й художніх біографій. У романі «Тарасові страсті» (2007), на основі документальних матеріалів, прозаїк звернувся до дослідження душі Т. Шевченка, а у творі «Се мого серця драма» (2010) - I. Франка. Прозаїк «відважився залучити в коло своїх творчих зацікавлень» [Різник 2015:137] відомих особистостей.

Творчий набуток 3. Легкого не часто ставав предметом спеціального літературознавчого аналізу. Можемо назвати рецензію В. Осадчого на роман «Тарасові страсті» [Осадчий 2007] та статтю Л. Різника до 75-річного ювілею 3 дня народження письменника «Цехмістер прозового цеху 3 Мурованого» [Різник 2015].

Об’єктом дослідження цієї розвідки обрано роман «Тарасові страсті» 3. Легкого. Мета статті - визначити способи трансформації історичної правди в художню в досліджуваному творі. Завданнями передбачено з'ясувати естетичне та композиційне навантаження документів у відтворенні 3. Легким подій, постатей тощо. Аналіз твору доповнить цілісну картину дослідницького сприйняття доробку прозаїка й літературного процесу ХХІ століття.

Відповідно до специфіки жанру, роман 3. Легкого «Тарасові страсті» базується на достовірних фактах із життя Т. Шевченка. Прикметно, що час оповіді - перебування поета за залізними гратами у Третьому відділі, органічно співіснує з часом минулим - це спогади арештанта. Поетапно головний герой заглиблюється в ланцюг життєвих подій від дитинства і до арешту та слідства в Петербурзі. Маємо детально виписані факти 3 життя Тараса (голодне дитинство; смерть матері; нелегке життя «межи зведенятами»; смерть батька; лупцювання дядька Павла; наймитські поневіряння в кирилівського дяка; старцювання; навчання в Академії мистецтв, подорож Україною й інші), що 
інтенсивно відроджуються в пам'яті героя. Можемо констатувати, що художнє зображення фактів у романі грунтується на документах, чому знаходимо підтвердження у працях біографів Т. Шевченка [див. Дзюба 2008, Кониський 1991]. Організації композиційно-наративної структури твору сприяють також часово-просторові форманти: Кирилівка, Моринці, Петербург, «22 квітня 1838! У руках відпускна» [Легкий 2006:3:50], «сороковий рік - рік похвальби й хули» [Легкий 2006:3:65], Качанівка, Суботів, Яготин, Мосівка, Березові Рудки, Глухів, Полтава, «28 жовтня я (Т. Шевченко - О. П.) вже у Вікторівиіі» [Легкий 2006:4:63], «i до 20 квітня я (Т. Шевченко - О. П.) уже у Києві» [Легкий 2006:4:67], «камінний Петербург - місие туги й самоти» [Легкий 2006:4:47] та інші.

Крім фактів із життя Т. Шевченка, у творі достатня кількість деталей певного історичного часу. Низка відомих для України подій, діячівне лише згадана, а ще й осмислена головним персонажем. Наприклад, роль Катерини II, яка зруйнувала Січ, загнала в Петропавловську фортецю «бунтовщиках уже Пугачова» письменника О. Радіщева за його «Путешествие из Петербурга в Москву». Маємо згадки про С. Наливайка, якого козацька верхівка, капітулювавши перед польським військом, видала ворогам на страту, про Б. Хмельницького, який покладав надію на союз із Росією, а потім каявся, про коліїв, яких підняв проти панів М. Залізняк, чи то про П. Калнишевського, останнього кошового отамана Запорозької Січі.

Отже, 3. Легкий продемонстрував знання багатьох фактів історичного минулого. Відтворена минувшина набула переконливості, висвітлюючи найсокровенніші думки, поглиблюючи конкретні обставини, у яких знаходився Т. Шевченко. Така форма нарації використана не лише для документального подання фактів, а й для вираження внутрішніх переживань головного героя, що допомагає передати процес функціонування людської психіки в усій іiі складності.

Документальність твору значно поглиблюе введення в контекст художньої біографії імен відомих особистостей. «Особистість в історії, як 
діалектично складному прочесі та безперервному русі, є головним об'єктом у дослідженні документально-біографічної прози» [Галич 1999:11]. Окремі епізоди в романі присвячено конкретним особистостям. З. Легкий демонструє обізнаність із біографічними джерелами про ту чи ту особуй подає вичерпну характеристику кожному. Наприклад, зі спогадів Т. Шевченка дізнаємося, що славнозвісний князь М. Рєпнін - рідний брат декабриста Сергія Волконського, був покровителем мистецтва, викупив із кріпацтва М. Щепкіна і знаходився в опозиції до самого царя. Згодом ці дані доповнюються докладною інформацією М. Щепкіна: «князь був малоросійським генерал-губернатором... А театр любив. Тому й переманив усю театральну трупу Штейна з Харкова до Полтави. Мене теж, бо пообіияв волю всій родині. Графиня Волкенштейн, якій ми належали, загилила 8000. Почали збори на відпускну. Князь підписав аж 200 карбованців. Прилучився до справи і його брат Сергій Волконський, потім Іван Котляревський та ще ц̆ ще. Намкребли тисяч чотири. Тоді ж Рєпнін додав ще стільки ж своӥх і оформив купчу на себе, тобто за півдарма кріпаків собі придбав. Стареньким через три роки дав вільну, а ось прачездатних жінок i чоловіків собі залишив, у тому числі й мене. Чому, брате? А захотілося мати в руках вже й душу народу - артиста... Аж сперегодом викупився я у нього» [Легкий 2006:4:50-51] та подальшими роздумами актора, що М. Рєпнін - це «ще одне розчарування в людській доброчесності ц̆ порядності <..> той вельможа, колишній європейський посланник й віще-король Саксонії, своєю зажерливістю позбавив щастя й рідну дочку» [Легкий 2006:4:51]. Сам «незрівнянний» М. Щепкін постає «з гладеньким округлим лищем $i$ щуирою лисиною, що так магічно приневолюе шанувальників-молодиків до субординаційної поштивості» [Легкий 2006:4:50], а у «примруженому оияі доброго Свгена (С. Гребінки - О. П.) виразно промовляє практична мудрість безсріберного малороса, перед якою й зв'ядає людська гординя» [Легкий 2006:3:64]. Найбільше уваги в романі приділено К. Брюллову, російському художнику, професору петербурзької Академії мистецтв, що мав велике значення для формування Шевченка-художника і став не лише 
вчителем, а й другом. Відповідність історичній правді допомогла також представити переконливі образи О. Афанасьєва-Чужбинського, Є. Гребінки, А. Козачковського, М. Костомарова, П. Куліша, Я. Кухаренка, В. Рєпніної, М. Рєпніна, І. Сошенка, М. Щепкіна, В. Штернберга й багатьох інших.

Документальності твору сприяє залучення виписок із історії Д. БантишаКаменського, «Історії Русів», досліджень М. Маркевича, а також відгуків на «Кобзар» (рецензія «малороса», «землячка» О. Нікітенка в журналі «Сын Отечества», «опікуна» О. Сенковського в «Библиотеке для чтения» № 39, П. Плетньова в «Современнике», Н. Кукольника, виголошена квітневого літературного вечора в М. Маркевича тощо). Менше уваги автор приділив листам - фіксуємо лише поодинокі виписки 3 листів Т. Шевченка до В. Григоровича, Г. Тарновського, П. Лукашевича та П. Куліша до Т. Шевченка.

Минувшина, а особливо історичні діячі, і не лише України, постають у цитованих творах самого Т. Шевченка - Петро I, Катерина II, П. Полуботок у поемі «Сон (Комедія)», батько Хмель у «Розритій могилі», Яків де Бальмен у «Кавказі» тощо.

Художня цінність роману 3. Легкого полягає не лише в моделюванні життєвої правди, а й у створенні обгрунтованого, вірогідного художнього домислу. Вдало додумав прозаїк особливості художнього мислення T. Шевченка при народженні багатьох творів. Менше уваги приділено малярській спадщині, більше - поетичній. 3. Легкий переконує, що саме 3 волі духовного розпорядника «соталися» рядки поезій. Прозаїк домислив моменти шукань виразних деталей, творчих вагань, сумнівів Т. Шевченка при народженні ряду поетичних творів, в основному періоду «трьох літ» «Тризна», «Розрита могила», «Чигрине, Чигрине», «Сон (Комедія)», «Сліпий (Поема)», «Великий льох (Містерія)», «Кавказ», «I мертвим, і живим...», «Холодний яр», «Як умру, то поховайте...». Прикметно, що відвідування відомих місць України допомагали уявляти майбутні сторінки поезій. Автор логічно підводить до картин, які виникали в уяві Т. Шевченка. Так, у с. Солониці поет згадав про Северина Наливайка, думкою сягаючи 1596 року, 
страшної драми українського життя, коли капітулювавши перед польським військом, козацька верхівка видала свого чільника ворогам на страту, на страшну смерть у мідному котлі: «... Наливайко не дає спокою - товчеться, тлумиться, вигупує в мені: знаю так буде доти, поки не виштовхаю його та не вжену у віри: сиди ж там, не катуй мене - читача тривож своїм життям $i$ смертю. Та коли то щуе буде! Коли ж виллю той біль! А позбудусь його - новий увійде в мене та й буде скимліти, гарчати, вити, невтоленний, до якогось часу» [Легкий 2006:4:57]. 3. Легкий продемонстрував знання багатьох творів Т. Шевченка і зафіксував їх у вигляді роздумів головного персонажа: «Москва своєю русифікацією, насильством і грабежем доведе до того, щзо народ знову повстане, знов пробудиться його національна свідомість - Великий льох України буде розкопано. 3 воронами й душами ясно. А ось три лірники... Нема в мене до них серияя: один сліпий, другий кривий, а третій горбун. Це ж інтелігенти наші, вчені, а мо', й писаки, щзо йдуть приспівувати гробокопачаммоскалям задля кусня хліба. Чи ж мало їх у нас таких? Й москалі докопалися, авжеж. Ось черепок. А иุе - гниле корито. І... кістяк у кайданах. Кістяк $у$ кайданах - трухло нашої минувшини, символ зрусифікованого пана чи генерала: чого б іщуе вартували вони за зраду, якої б щуе їм винагороди за відступництво, крім залізних пут? Спокутуйте ж гріх! Без відпокути нема прощення» [Легкий 2006:4:66]. Детально домислені епізоди створення живописної «Катерини», згадано про роботу над малярськими полотнами - «У Києві», «Судня рада», «Дари в Чигрині 1649 року», «Старости», «Коло Седнева», «У Седневі» тощо. Тож, прозаїку вдалося розкрити процеси творчих шукань Шевченка-художника i Шевченка-письменника: «уже берусь за ескіз до офорту «Старости». Тільки ж до образів, щзо маячать мені перед очима, брикливий олівещьь сліпий $і$ знай собі виписує слова, нечема:

Стоїв в селі Суботові

На горі високій

Домовина Украӥни...» [Легкий 2006:4:50]. 
За переконаннями 3. Легкого Т. Шевченко «присилував себе до малювання». Під час роботи над художніми полотнами, ніби хтось гупає, дуднить, дзвонить, волає, і поет мусить записувати. Із великою увагою прозаїк поставився до духовного життя історичної особи. У вигаданих автором внутрішніх монологах головний персонаж висловив найпотаємніше: «серце моє спустошене, віра в добрих панів погасла, кругом мене, бодай не казати, не люди, а змї. Бог тяжко покарав мене мистецьким хистом: навчив пізнавати людей, щуоби гірко розчаровуватися в них... кривава тая слава!» [Легкий 2006:4:65]. Т. Шевченко сповідується, що, подорожуючи Україною, шукав по всіх усюдах історичні й культурні пам’ятки, а споглядав, змальовував і описував одні руїни. Домисленими у романі є численні роздуми головного персонажа про долю, якою йому передбачено метатися демоном між вічністю і небуттям і «кричати всім, хто вміє слухати: живіть за правдою, бо тлінна людська плоть, а безсмертна душа приречена на вічні муки за прогрішення під сонцем» [Легкий 2006:4:65], про немилосердність долі: «... не вмів помануватися? Багато брав на себе? Сповна віддався деміургові?» [Легкий 2006:3:43], про самотність: «чужий... самотній безталанник, з’їаюся каяттям, пощуо покинув рідний край. Чого домігся в чужині - втіхи пізнання?» [Легкий 2006:4:43], чи то роль митця: «... хто б міг подумати, щзо незборне поривання до високого мистецтвв, до божественного діяння приведе мене сюди, в каземат? Може, щзо ия дорога до прекрасного вистелена гріхами?» [Легкий 2006:3:34-35], поет «має муркотіти домашнім котиком, стелитися нижче трави чи навіть велемудро мовчати <..> та в мені <..> вже збудився біс, дух спротиву розпростав плечі ц̌ хребет. Чому маю зрікатися себе чи ховатися слимаком у панциирну хатинку? Ніколи в світі!» [Легкий 2006:4:61] тощо. Подібні внутрішні монологи відтворюють невисловлені відчуття, приховані переживання й думки головного персонажа.

Образ поета розкривається і через показ вигаданих сцен-зустрічей. У контексті твору художньо вмотивовані, народжені творчою уявою прозаїка, зустрічі Т. Шевченка 3 О. Афанасьєвим-Чужбинським, Є. Гребінкою, 

В. Репніною,
А. Козачковським,
М. Костомаровим,
Ф. Ткаченком,

М. Щепкіним та багатьма іншими. Акцентовано увагу на дружніх стосунках поета 3 названими особистостями. Ф. Лазаревський свідчив, що в поета була маса знайомих, яка дорожила його товариством [детальніше див. Біографія 1984:245-246].

Отже, сюжетний розвиток у романі 3. Легкого «Тарасові страсті» грунтується на достовірних фактах із життя Т. Шевченка та його оточення. Автор майстерно синтезував біографічні відомості з обгрунтованим, вірогідним домислом. Твір прозаїка органічно вписався в контекст українських художній біографій. Представлене ж дослідження не $\epsilon$ вичерпним і подальші розробки 3 цієї тематики допоможуть краще осягнути специфіку означених творів.

\section{БІБЛІОГРАФІЯ}

Біографія 1984 - Т.Г. Шевченко : біографія / В. Бородін, Є. П. Кирилюк, В. Л. Смілянська, Є. С. Шабліовський, В. С. Шубравський ; [відп. ред. Є. П. Кирилюк]. - К. : Наукова думка, 1984. - 558 с.

Галич 1999 - Галич О. Художня біографія : проблеми теорії та історії : монографія / О. А. Галич, О. О. Дацюк, Л. В. Мороз. - Рівне, 1999. - 94 с.

Дзюба 2008 - Дзюба I. Тарас Шевченко : життя і творчість / I. Дзюба. К. : Вид. дім «Києво-Могилянська академія», 2008. - 720 с.

Кониський 1991 - Кониський О. Тарас Шевченко-Грушівський : хроніка його життя / Олександр Кониський. - К. : Дніпро, 1991. - 702 с.

Легкий 2006 - Легкий 3. Тарасові страсті : роман / Зіновій Легкий// Дзвін. - 2006. - № 3. - С. 26-76.

Легкий 2006 - Легкий 3. Тарасові страсті : роман / Зіновій Легкий // Дзвін. - 2006. - № 4. - С. 33-90.

Осадчий 2007 - Осадчий В. Між берегами добра і зла / Василь Осадчий // Літературна Україна. - 2007. - 20 вересня.

Різник 2015 - Різник Л. Цехмістер прозового цеху з Мурованого / Левко Різник // Дзвін. - 2015. - № 1. - С. 135-140. 